\section{Using Movable Light-emitting Diodes for Electricity Savings in a Plant Factory Growing Lettuce}

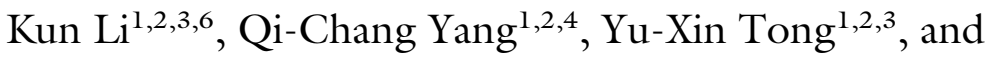 \\ Ruifeng Cheng ${ }^{1,2,5}$
}

ADDITIONAL INDEX wORDs. ascorbic acid, chlorophyll, fructose, glucose, Lactuca sativa, sucrose

Summary. In this study, the effects of light-emitting diode (LED) panels with different illumination schedules and mounted above butterhead lettuce (Lactuca sativa var. capitata) seedlings on lettuce growth and photosynthesis were examined, and the performance of the vertical and horizontal movable system on energy savings was evaluated. The illumination schedules used were fixed LED [F-LED (four LED panels illuminated the area below)] and movable LED [M-LED (two LED panels moved left and right once per day to illuminate the same area as F-LED)] at distances of 10 and $30 \mathrm{~cm}$ above the seedlings. The plant yields were uniform in all LED treatments. The highest light utilization efficiencies and lowest electricity consumption were found for the treatments with irradiation from a shorter distance above the seedlings. The true leaf numbers and ascorbic acid concentrations were the highest in the M-LED and F-LED treatments at a distance above the seedlings of $10 \mathrm{~cm}$, while the leaf lengths and sucrose concentrations in these groups were significantly lower than those in the $30-\mathrm{cm}$ treatment. These results indicate that illumination with $M$-LED can halve the initial light source input while maintaining yield and that sustained illumination from a shorter distance above the seedlings is the main factor in electricity savings.

$\mathrm{P}$ lant factories with artificial lighting are widely used in many areas (Hahn et al., 1996; Ikeda et al., 1992; Ioslovich and Gutman, 2000; Kato et al., 2010; McAvoy et al., 1989; Morimoto et al., 1995) as an ideal model for precision agriculture (Murase, 2000), in which artificial lights play an important role in the precise control of the light environment. However, the widespread use of plant factories with artificial lighting is

This project was funded by the National High Technology Research and Development Plan of China $(863$ Project, grant No.2011AA03Al 14; 2013AAl03001), the National Science and Technology Pillar Program (grant No.2011BAE01Bl0), and the Basic Scientific Research Fund of National Nonprofit Institutes, Institute of Environment and Sustainable Development in Agriculture, Chinese Academy of Agricultural Sciences.

We thank Xian-Chun Xia and Jun-Jie Fu for their critical review and improvement of the manuscript, and Wen-Ke Liu and Ping Xiao for providing technical support.

${ }^{1}$ Institute of Environment and Sustainable Development in Agriculture, Chinese Academy of Agricultural Sciences, Beijing 100081, China

${ }^{2} \mathrm{Key}$ Lab of Energy Conservation and Waster Treatment of Agricultural Structures, Ministry of Agriculture, Beijing 100081, China

${ }^{3}$ Assistant Professor

${ }^{4}$ Professor

${ }^{5}$ Associate Professor

${ }^{6}$ Corresponding author. E-mail: vista-lee@vista.aero. limited by their high initial investment and operation costs, which are mainly attributable to the costs of electricity for artificial lighting (Ohyama et al., 2001). With the continuous expansion of plant factories, reducing the initial investment and electric-energy consumption of artificial lighting has become increasingly important.

Several possible solutions for reducing the electricity consumption of lighting have been studied. Nishimura et al. (2001) estimated reductions of $50 \%$ in the electricity consumption of lamps by improving the efficiency of the lighting. Yamada et al. (2000) found that stepwise photosynthetic photon flux $(P P F)$ control was a useful method for reducing the electricity consumption of lighting and increasing the electricity utilization efficiency. Bao et al. (2008) integrated a photovoltaic power generating system into a plant factory to reduce dependence on the commercial grid. However, these solutions either have limited effects on electricity savings or are associated with high costs of equipment construction.

As an attractive alternative to traditional light sources, LEDs have been widely used in potential energy saving applications such as rooms (Ryckaert et al., 2012), supermarkets (Elsevier Science, 2006), tunnels (Zeng et al., 2011), and even in coastal fishing boats (Matsushita et al., 2012).

Because of their tailorable spectral composition, wavelength specificity, and narrow bandwidth, LEDs have been widely used to examine the effects of different environmental light parameters on plant growth, phytochemical processes, or both. Kitaya et al. (1998) found that the leaf number of lettuce increased with increasing PPF. The phenolic concentration of lettuce has been reported to increase by $6 \%$ under supplemental red light, while supplemental far-red light decreased anthocyanin, carotenoid and, chlorophyll (Chl) concentrations by $40 \%, 11 \%$, and $14 \%$, respectively ( $\mathrm{Li}$ and Kubota, 2009). Green-light supplementation has been reported to stimulate a rapid increase in the growth rate of etiolated arabidopsis seedlings [Arabidopsis thaliana (Folta, 2004)], ascorbic acid accumulation (Samuolienè et al., 2012), and lettuce growth (Kim et al., 2004), but showed a negative effect on biomass production (Folta and Maruhnich, 2007). Previous studies have also indicated that blue light is essential for leaf expansion and biomass

\begin{tabular}{llll}
\hline $\begin{array}{l}\text { Units } \\
\text { To convert U.S. to SI, } \\
\text { multiply by }\end{array}$ & U.S. unit & SI unit & $\begin{array}{l}\text { To convert SI to U.S., } \\
\text { multiply by }\end{array}$ \\
\hline 29.5735 & $\mathrm{fl} \mathrm{oz}$ & $\mathrm{mL}$ & 0.0338 \\
0.0929 & $\mathrm{ft}^{2}$ & $\mathrm{~m}^{2}$ & 10.7639 \\
2.54 & inch $(\mathrm{es})$ & $\mathrm{cm}$ & 0.3937 \\
25.4 & inch $(\mathrm{es})$ & $\mathrm{mm}$ & 0.0394 \\
1 & micron $(\mathrm{s})$ & $\mu \mathrm{m}$ & 1 \\
1 & $\mathrm{mmho} / \mathrm{cm}$ & $\mathrm{mS} \cdot \mathrm{cm}^{-1}$ & 1 \\
28.3495 & $\mathrm{oz}$ & $\mathrm{g}$ & 0.0353 \\
28,350 & $\mathrm{oz}$ & $\mathrm{mg}$ & $3.5274 \times 10^{-5}$ \\
305.1517 & $\mathrm{oz} / \mathrm{ft}^{2}$ & $\mathrm{~g} \cdot \mathrm{m}^{-2}$ & 0.0033 \\
0.001 & $\mathrm{ppm}$ & $\mathrm{mg} \cdot \mathrm{g}^{-1}$ & 1000 \\
$\left({ }^{\circ} \mathrm{F}-32\right) \div 1.8$ & ${ }^{\circ} \mathrm{F}$ & ${ }^{\circ} \mathrm{C}$ & $\left({ }^{\circ} \mathrm{C} \times 1.8\right)+32$
\end{tabular}


production (Hogewoning et al., 2010; Johkan et al., 2012; Li et al., 2010) and also plays an important role in Chl synthesis (Kurilčik et al., 2008; Li et al., 2012; Poudel et al., 2008; Senger, 1982), but the much higher blue fraction in fluorescent lamps (FL), compared with highpressure sodium lamps, incandescent lamps, and LEDs, may not effectively interact with the plant (Dougher and Bugbee, 2001). Li and Kubota (2009) have shown that the ascorbic acid concentration in lettuce is sensitive to none of the abovementioned spectra of light, reaching the opposite conclusion of Ohashi-Kaneko et al. (2007), who reported that the ascorbic acid content in leaf lettuce increased under irradiation by blue or red-blue light. However, few studies have focused on the electricity savings of LEDs.

A movable system was built for this study, and its benefits were evaluated by analyzing the electricity consumption of the lighting as well as the plant growth, plant physiology, and phytochemical accumulation of the lettuce grown under different lighting modes. The objective of this research was to develop a lighting system for lettuce production in a plant factory by halving the electric input of the original light sources while providing high $P P F$ with low electricity consumption and maintaining lettuce yield and quality.

\section{Materials and methods}

Plant materials and growth CONDITIONs. Butterhead lettuce seeds were sown in a plastic seedling tray $(57 \times$ $23.5 \times 4 \mathrm{~cm}$ ) containing a substrate mix of 1 peat: 1 vermiculite (by volume), germinated in a tempered glass covered greenhouse at the Chinese Academy of Agricultural Sciences (CAAS), Beijing, China (lat. $39^{\circ} 57^{\prime} 34.89^{\prime \prime} \mathrm{N}$, long. $\left.116^{\circ} 19^{\prime} 13.03^{\prime \prime} \mathrm{E}\right)$ under ambient light and irrigated with tap water once per day. When the first true leaf $(\approx 5$ $\mathrm{mm}$ in length) appeared $\approx 15 \mathrm{~d}$ after sowing, nine uniform seedlings were selected and transplanted onto cultivation boards (polyethylene, $110 \times$ $60 \times 14 \mathrm{~cm}, 18$ plants $/ \mathrm{m}^{2}$ ) in an $25-\mathrm{m}^{2}$ industrial computer-controlled, fully closed plant factory at CAAS, Beijing, China (lat. $39^{\circ} 57^{\prime} 35.09^{\prime \prime} \mathrm{N}$, long. $116^{\circ} 19^{\prime} 12.71^{\prime \prime} \mathrm{E}$ ) and were cultivated with the deep flow technique (Hu et al., 2008) for $30 \mathrm{~d}$ and maintained under a 10 -h photoperiod
(Wen, 2009). The air temperature was maintained at $20^{\circ} \mathrm{C}$, while the mean canopy in each treatment described below was $( \pm \mathrm{SE}) 23.5 \pm 0.5 / 21 \pm$ $0.5{ }^{\circ} \mathrm{C}$ (light/dark cycle), synchronized with the operation of the light sources. The humidity was $60 \%$ to $80 \%$, and the carbon dioxide concentration was kept consistent with the atmosphere by ventilating at a rate of one air exchange every $3.5 \mathrm{~h}$ during the day and every $5 \mathrm{~h}$ at night. Fresh nutrient solution $[( \pm \mathrm{SE}) \mathrm{pH} 6.3 \pm 0.1$, EC $\left.1.6 \pm 0.1 \mathrm{mS} \cdot \mathrm{cm}^{-1}\right]$ was circulated for $15 \mathrm{~min}$ every $12 \mathrm{~h}$. The air temperature and humidity were measured twice per day; the parameters of the nutrient solution were monitored daily.

Light Treatments. A movable system (Delta Electronics, Taipei, China) was built (Fig. 1); the system was composed of a movable metal frame $(125 \times 60 \times 80 \mathrm{~cm})$ driven by two groups of programmable motion control servo motors, which provided automatic horizontal and vertical movement. Custom-manufactured LED panels $(60 \times 25 \times 1.2 \mathrm{~cm}$; FHT Co., Shenzhen, China) with red (peak at $630 \mathrm{~nm}$ ) and blue (peak at $460 \mathrm{~nm}$ ) LEDs were used as the main light source and were placed horizontally 10 or $30 \mathrm{~cm}$ above the seedlings inside the plant factory to obtain the illumination schedule described below. The light treatments examined in this experiment are shown in Table 1 and Fig. 2 and included T8 FL (YZ18RR26, $18 \mathrm{~W}$ temperature measured at the top of the

each, electrical ballast NEB118/T8$\mathrm{EM}$, power factor $=0.98 ;$ NVC Co., Huizhou, China) as the control [FL (Fig. 2A)], four LED panels fixed $30 \mathrm{~cm}$ directly above the seedlings [F-LED30 (Fig. 2B)], two LED panels attached to the movable metal frame $30 \mathrm{~cm}$ above the seedlings [M-LED30 (Fig. 2C)], two LED panels attached to the movable metal frame $10 \mathrm{~cm}$ above the seedlings [M-LED10 (Fig. 2D)], and four LED panels fixed $10 \mathrm{~cm}$ directly above the seedlings [F-LEDl0 (Fig. 2E)]. The FLs in control were covered with an aluminum foil reflector. The red-blue ratio $(\mathrm{R} / \mathrm{B})$ for all LED panels was kept at 8:1 (Wen, 2009). Each treatment and control covered $0.5 \mathrm{~m}^{2}$ (completely covering the growing area of the plants below), and spectral energy distribution scans were recorded at 400 to $800 \mathrm{~nm}$ with $2-\mathrm{nm}$ steps of the LEDs and FL (Fig. 3) with a calibrated fiber optic spectrometer (AvaSpec-2048; Avantes, Apeldoorn, The Netherlands) placed horizontally under the light sources used for the experiments.

The FL and F-LED30 employed the light sources hanging $30 \mathrm{~cm}$ above the seedlings to simulate the current cultivation mode widely used in plant factories. The $P P F 15 \mathrm{~cm}$ from the lighting panels were kept at $150 \mu \mathrm{mol} \cdot \mathrm{m}^{-2} \cdot \mathrm{s}^{-1}$; the illumination times were $10 \mathrm{~h}$ per day $(0700$ to $1700 \mathrm{HR})$.

To halve the investment of light sources, the M-LED30 employed two LED panels hanging $30 \mathrm{~cm}$

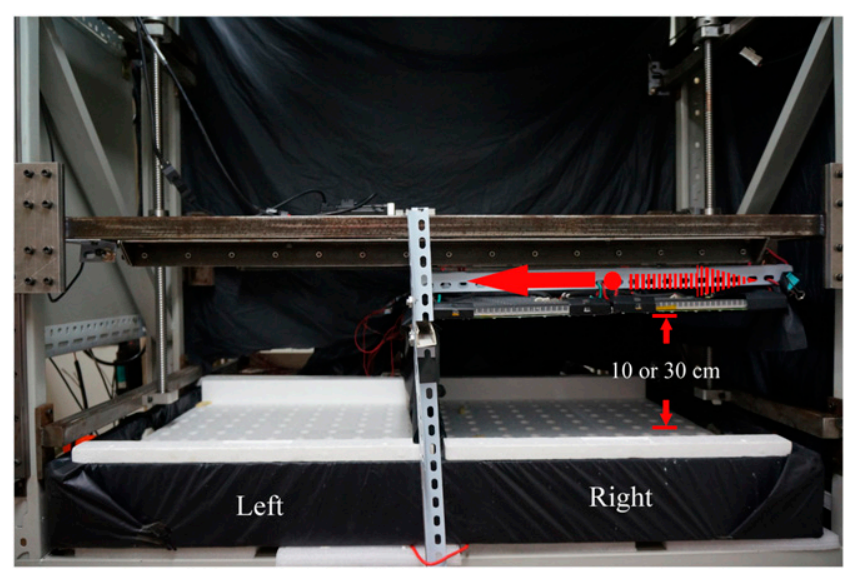

Fig. 1. The movable system used in this study (Delta Electronics, Taipei, China). The light-emitting diode (LED) panels $(60 \times 25 \times 1.2 \mathrm{~cm}$; FHT Co., Shenzhen, China) were located on the right side and 10 or $30 \mathrm{~cm}$ away from the seedling. After $12 \mathrm{~h}$, the LED panels moved to the left side in several minutes (regardless of the speed); $1 \mathrm{~cm}=0.3937$ inch. 
Table 1. Light environment parameters, including composition of light sources, distance between the light source and the lettuce, lighting time, light intensity, fraction and ration of different spectral of lights and daily light integral (DLI) of treatments with fluorescent lamps (FL) as the control, four light-emitting diode (LED) panels fixed $30 \mathrm{~cm}$ (11.8 inches) directly above the seedling (F-LED30), two LED panels attached to the movable system $30 \mathrm{~cm}$ above the seedlings (MLED30), two LED panels attached to the movable system $10 \mathrm{~cm}(3.9$ inches) above the seedlings (M-LEDI0), and four LED panels fixed $10 \mathrm{~cm}$ directly above the seedlings (F-LED10).

\begin{tabular}{|c|c|c|c|c|c|}
\hline \multirow[b]{2}{*}{$\underline{\text { Parameter }}$} & \multicolumn{5}{|c|}{ Treatment } \\
\hline & M-LED10 & F-LED10 & M-LED30 & F-LED30 & FL \\
\hline Lighting sources ${ }^{\mathrm{z}}$ & LED panel $\times 2$ & LED panel $\times 4$ & LED panel $\times 2$ & LED panel $\times 4$ & T8 tube $\times 8$ \\
\hline Lighting time $\left(h \cdot d^{-1}\right)^{x}$ & $10 \times 2$ & 10 & $10 \times 2$ & 10 & 10 \\
\hline \multicolumn{6}{|c|}{ Light intensity $\left(\mu \mathrm{mol} \cdot \mathrm{m}^{-2} \cdot \mathrm{s}^{-1}\right)^{\mathrm{w}}$} \\
\hline$P P F(400-700 \mathrm{~nm})$ & 150 & 150 & 150 & 150 & 150 \\
\hline $\operatorname{Red}(600-700 \mathrm{~nm})$ & 133 & 133 & 133 & 133 & 39 \\
\hline Far-red $(700-800 \mathrm{~nm})$ & 0 & 0 & 0 & 0 & 7 \\
\hline $\operatorname{DLI}\left(\mathrm{mol} \cdot \mathrm{m}^{-2} \cdot \mathrm{d}^{-1}\right)^{\mathrm{v}}$ & 12.96 & 12.96 & 4.32 to 12.96 & 4.32 to 12.96 & 4.75 to 10.97 \\
\hline \multicolumn{6}{|l|}{ Fraction $(\%)$} \\
\hline$P P F$ & 100 & 100 & 100 & 100 & 100 \\
\hline Red:far-red & Infinite & Infinite & Infinite & Infinite & 5.6 \\
\hline Red:blue & 7.8 & 7.8 & 7.8 & 7.8 & 0.8 \\
\hline
\end{tabular}

${ }^{2}$ The $\times 2, \times 4$, and $\times 8$ indicate two, four, and eight units of each lighting sources.

y The distance from the light source where the specific photosynthetic photon flux $(P P F)$ is achieved; $1 \mathrm{~cm}=0.3937$ inch.

${ }^{x}$ The $\times 2$ indicate both the left and right side was exposed to a 10 -h photoperiod each.

wThe $P P F$ under designated height of each treatment.

vThe DLI value were calculated based on periodic measurements, and increased with the growth of lettuce, while the light sources were anchored $30 \mathrm{~cm}$ above the seedling from the beginning of the experiments.

above the seedlings, the PPF $15 \mathrm{~cm}$ from the lighting panels were kept at $150 \mu \mathrm{mol} \cdot \mathrm{m}^{-2} \cdot \mathrm{s}^{-1}$; the illumination time was $20 \mathrm{~h}$ per day (0700 to $1700 \mathrm{HR}$ and 1900 to $0500 \mathrm{HR}$ ).

For further improvement of current cultivation mode, the M-LEDI0 was conducted, in which the distance between the top of the seedlings and the lighting panels were kept at $10 \mathrm{~cm}$ by manually elevating the metal frame once every 1 to $2 \mathrm{~d}$ according to the growth rate of the lettuce at different growth stages. The PPF (150 $\left.\mu \mathrm{mol} \cdot \mathrm{m}^{-2} \cdot \mathrm{s}^{-1}\right)$ were set up with no changes by adjusting the luminous intensity of the individual LEDs. The illumination time was $20 \mathrm{~h}$ per day $(0700$ to $1700 \mathrm{HR}$ and 1900 to $0500 \mathrm{HR})$.

To decide if the distance is the only major factor affecting plant growth, the F-LEDl0 is added. Four LED panels were kept at $10 \mathrm{~cm}$ manually. The $P P F\left(150 \mu \mathrm{mol} \cdot \mathrm{m}^{-2} \cdot \mathrm{s}^{-1}\right)$ were set up with no changes by adjusting the luminous intensity of the individual LEDs. The illumination time was $10 \mathrm{~h}$ per day $(0700$ to $1700 \mathrm{HR})$.
The planters below M-LEDI0 and M-LED30 were carefully divided into the left half and right half sides by black films to ensure that no light spilled over from one side to the other; half the number of LED panels were attached to the metal frame and underwent a horizontally back and forth motion to the left or to the right once over several minutes every $12 \mathrm{~h}$ regardless of the speed (Fig. 1 and Table 1), illuminating the same plant area as in the F-LEDs while providing light for $20 \mathrm{~h}$ per day (0700 to $1700 \mathrm{HR}$ and 1900 to $0500 \mathrm{HR}, \mathrm{L}$ and $\mathrm{R}$ growing area was exposed to a 10-h photoperiod each) (Fig. 4) throughout the entire growth period. Each treatment and control was isolated by black films to prevent light contamination during the experiment. No differences were observed for the plants grown and phytochemical accumulation on the left and right sides under the M-LED treatments. The fiber optic spectrometer was employed to measure the PPF. As an criterion indicator of the total amount of instantaneous light received by plants, the daily light integral (DLI) was calculated with the $P P F$ detected at the heights of the plant canopy at certain growing stages (Table l) to further illustrate the light quantity of different illumination schedules.

Measurements. Thirty days after the start of the lighting treatments, the plants under the five treatments were harvested to measure their growth and to analyze their phytochemical concentrations. The leaf fresh weight (FW), plant height, number of leaves, leaf length and leaf Chl concentrations were measured immediately after harvest [the dry weight (DW) was not measured because of the fresh tissue sampling for Chl concentration from every plant]. The remaining leaves were packaged in plastic bags and moved to an ultralow temperature refrigerator, freezedried in a bench-top freeze-dryer (ALPHA 2-4 LD; Martin Christ Gefriertrocknungsanlagen, Osterode am Harz, Germany), and then ground into a powder. The freezedried samples were stored at $-20{ }^{\circ} \mathrm{C}$ and used to determine the ascorbic acid and soluble sugar (fructose, glucose, and sucrose) concentrations. An 


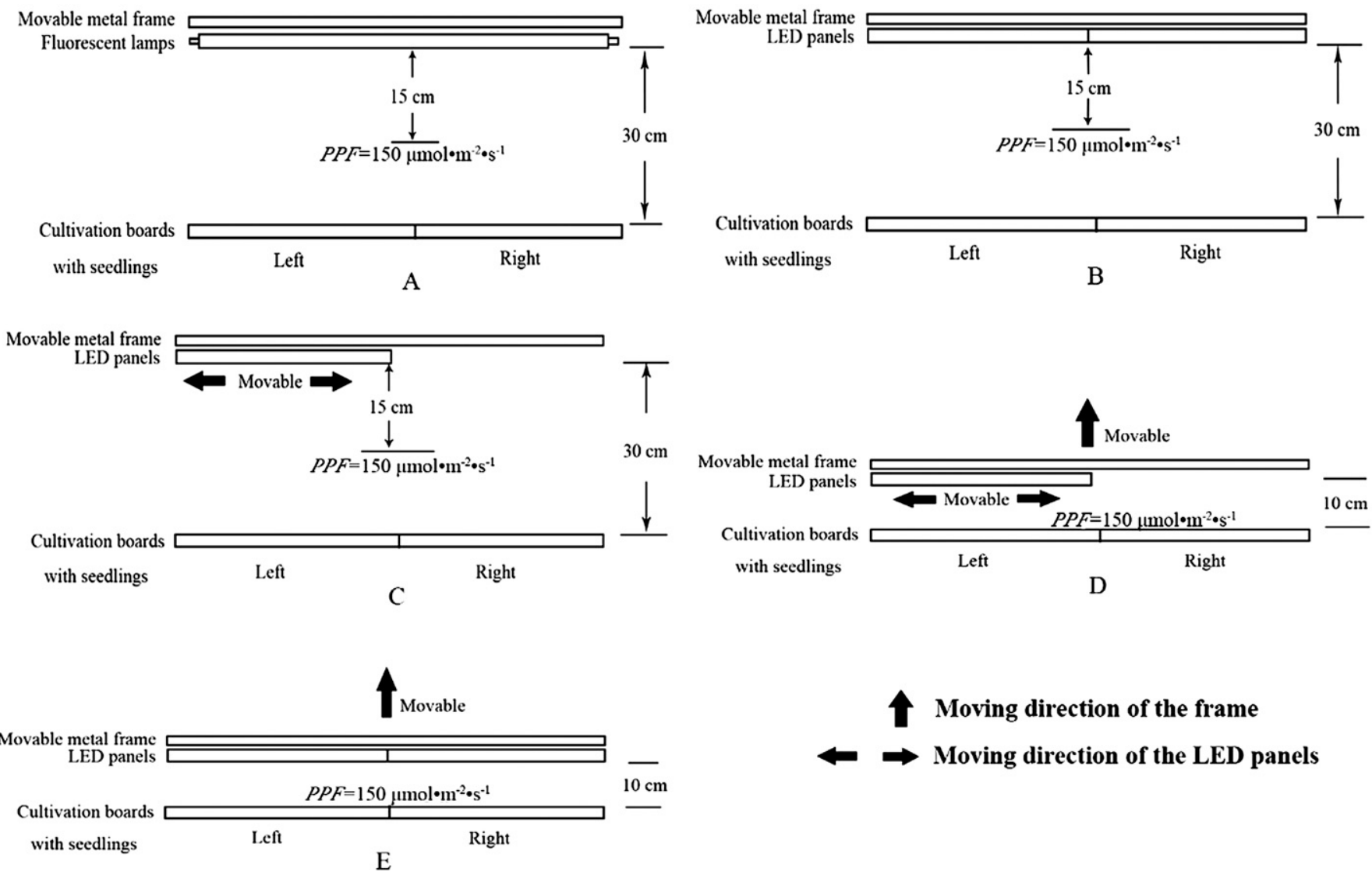

Fig. 2. The light treatments examined in the present experiment composed of (A) T8 fluorescent lamps as the control (FL), (B) four light-emitting diode (LED) panels fixed $30 \mathrm{~cm}$ directly above the seedlings (F-LED30), (C) two LED panels attached to the movable metal frame $30 \mathrm{~cm}$ above the seedlings (M-LED30), (D) two LED panels attached to the movable metal frame $10 \mathrm{~cm}$ above the seedlings (M-LED10), and (E) four LED panels fixed $10 \mathrm{~cm}$ directly above the seedlings (F-LED10). The large arrows indicate the horizontal moving directions (left and right) and vertical moving directions; $P P F=$ photosynthetic photon flux, $1 \mathrm{~cm}=0.3937$ inch.

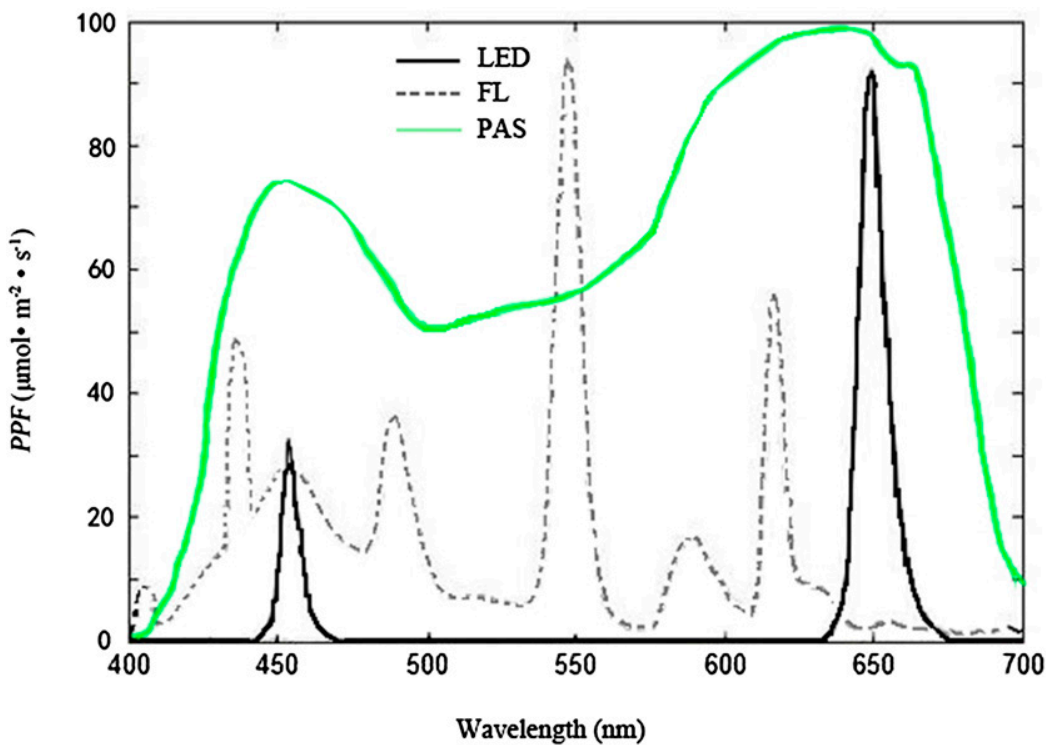

Fig. 3. Spectral distributions of light from light-emitting diode (LED) and fluorescent lamps (FL) measured with a fiber optic spectrometer (AvaSpec-2048; Avantes, Apeldoorn, The Netherlands), and plant absorption spectrum (PAS) reported by Sager et al. (1982); PPF = photosynthetic photon flux. electricity meter (LCDG-ZJ120-01; LiChuang Science and Technology Co., Laiwu, China) was employed to measure the electricity consumption of the lighting (the energy costs for cooling, ventilation, and the recirculation of the nutrient solution were not considered during our experiments). The light utilization efficiency [LUE (grams per kilowatt hour)] of each treatment was determined $[\mathrm{LUE}=$ leaf FW (grams per plant $) \times 18$ plants $/ \mathrm{m}^{2} /$ electricenergy consumption of lighting (kilowatts per hour)]. Fresh leaf tissue $(2 \mathrm{~g})$ was extracted in $20 \mathrm{~mL}$ of $80 \%$ acetone/water (v/v) overnight at $4{ }^{\circ} \mathrm{C}$ in the dark. The extract was centrifuged (3K15; Sigma Laborzentrifugen, Osterode am Harz, Germany) at $10,000 g_{n}$ for $10 \mathrm{~min}$, and the supernatant was used for the spectrophotometric determination of chlorophyll a (Chl a) and chlorophyll b (Chl b) with a spectrophotometer 
(ultraviolet-1800; Shimadzu Corp., Kyoto, Japan) at $663 \mathrm{~nm}$ (A663) and 646 nm (A646) wavelengths, respectively. The concentrations (milligrams per gram FW) of Chl a and Chl b were determined from the following equations: $\mathrm{Chl} \mathrm{a}=(12.21$ $\times$ A663 - $2.81 \times$ A646) $\times 20 / 1000 / 2$

\section{F-LED}

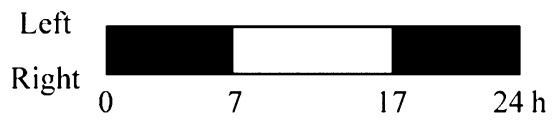

M-LED

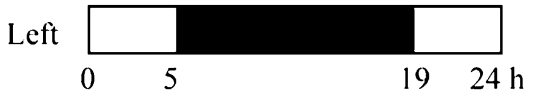

Right

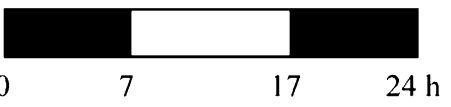

Photoperiod

Dark period

Fig. 4. The illumination schedules of treatments: four light-emitting diode (LED) panels fixed $30 \mathrm{~cm}$ (11.8 inches) directly above the seedling of lettuce (F-LED30), two LED panels attached to the movable system $30 \mathrm{~cm}$ above the seedlings (M-LED30), two LED panels attached to the movable system $10 \mathrm{~cm}$ (3.9 inches) above the seedlings ( $\mathrm{M}$ LED 10), and four LED panels fixed 10 $\mathrm{cm}$ directly above the seedlings ( $\mathrm{F}$ LED10). The F-LED treatments ( $F$ LED10 and F-LED30) illumination time were $10 \mathrm{~h}$ per day (0700 to 1700 $\mathrm{HR}$ ) on both the left and right side of the planter; the M-LED treatments (MLED10 and M-LED30) were $20 \mathrm{~h}$ per day (0700 to $1700 \mathrm{HR}$ and 1900 to $0500 \mathrm{HR}$ ), reciprocating horizontally left and right once every $12 \mathrm{~h}$. For the M-LED treatments, the left and right side of the growing area each received $10 \mathrm{~h}$ of continuous lighting over a 24-h period. and $\mathrm{Chl} \mathrm{b}=(20.13 \times \mathrm{A} 646-5.03 \times$ A663) $\times 20 / 1000 / 2$, following Lichtentaler and Wellburn (1983). Freeze-dried samples $(50 \mathrm{mg})$ were extracted in $10 \mathrm{~mL}$ of $50 \%$ ethanol solution and incubated in a water bath at $85^{\circ} \mathrm{C}$ for $30 \mathrm{~min}$. The samples were cooled to room temperature, and alcohol was added to the original weight; the extract solution was then centrifuged at $10,000 g_{\mathrm{n}}$ for $10 \mathrm{~min}$, and the supernatant was collected. The pellet was re-extracted twice with the same solvent, and the supernatants were combined for soluble sugar measurement by a high-performance liquid chromatography (HPLC; Waters, Milford, MA) system equipped with an amino column (Xbridge Amide, $4.6 \times 250 \mathrm{~mm}, 3.5 \mu \mathrm{m}$; Waters). The eluent absorbance was measured, and the sugar concentrations were determined against fructose, glucose, and sucrose standards (SigmaAldrich, St. Louis, MO) by HPLC, following the AOAC Official Method 982.14 (Association of Official Analytical Chemists International, 2006). Ascorbic acid was determined as described by Gahler et al. (2003) with some modifications. Freeze-dried samples $(20 \mathrm{mg})$ were extracted in $3 \mathrm{~mL}$ of $4.5 \%$ aqueous phosphoric acid for $30 \mathrm{~min}$ in darkness, shaken frequently, and then centrifuged at $3000 g_{\mathrm{n}}$ for $10 \mathrm{~min}$. The supernatants were used to determine the concentration of ascorbic acid by using an HPLC system equipped with a Cl8 column (Shim-pack VP-ODS C18, $150 \times 4.6 \mathrm{~mm}, 5 \mu \mathrm{m}$; Shimadzu Corp.) and maintained at $30{ }^{\circ} \mathrm{C}$, with a mobile phase $(0.21 \%$ o-phosphoric acid) at a flow rate of $0.8 \mathrm{~mL} \cdot \mathrm{min}^{-1}$. The eluent absorbance was measured at $254 \mathrm{~nm}$ and the concentrations were determined against ascorbic acid standards (Sigma-Aldrich).

ExPERIMENTAL DESIGN AND STATISTICAL ANALYSIS. The experiment was performed twice, and plant measurements represent means of 18 plants, consisting of nine plants per treatment and repeated two times each. The results were analyzed with SAS statistical software (version 9.2; SAS Institute, Cary, NC). Data were analyzed by analysis of variance, and different letters within the column indicate significant differences at $P \leq$ 0.05 according to least significant difference test.

\section{Results and discussion}

\section{ELECTRIC-ENERGY CONSUMPTION} OF THE LIGHTING SYSTEMS. When used as an alternative to fluorescent lights, the F-LED (F-LEDI0, FLED30) and M-LED (M-LED10, M-LED30) consumed much less $(29.4 \%$ to $42.4 \%)$ electricity than the $\mathrm{FL}$, and the plant yield increased significantly (Table 2). Benefitting from their decreased distance to the plants, the M-LEDI0 and F-LEDI0 achieved further reductions ( $15.0 \%$ to $18.4 \%$, respectively) in energy consumption and $20.0 \%$ to $18.5 \%$ increase in LUE relative to M-LED30 and F-LED30, respectively, allowing the plants to obtain the desired illumination with minimal energy consumption.

However, considering the light uniformity under the LED panels, there was a minimum distance between LED panels and plant, which was determined by the luminescence angle of LEDs. Specific to the LED panels we used in our research, the minimum distance, also the optimal

Table 2. Electricity consumption of lighting, plant yields and light utilization efficiencies (LUEs) of lettuce under fluorescent lamps (FL), four light-emitting diode (LED) panels fixed $30 \mathrm{~cm}$ (11.8 inches) directly above the seedling (F-LED30), two LED panels attached to the movable system $30 \mathrm{~cm}$ above the seedlings (M-LED30), two LED panels attached to the movable system $10 \mathrm{~cm}$ (3.9 inches) above the seedlings (M-LED10), and four LED panels fixed $10 \mathrm{~cm}$ directly above the seedlings (F-LED10).The electricity consumptions were recorded with an electricity meter.

\begin{tabular}{lccr}
\hline Treatment & Electricity consumption $\left(\mathrm{kWh} / \mathrm{m}^{2}\right)^{\mathrm{z}}$ & Plant yields $\left[\text { mean } \pm \mathrm{sD}\left(\mathrm{g} \cdot \mathrm{m}^{-2}\right)\right]^{\mathrm{y}}$ & LUEs $[\mathrm{mean} \pm \mathrm{SD}(\mathrm{g} / \mathrm{kWh})]^{\mathrm{x}}$ \\
\hline M-LED10 & 61.2 & $625.9 \pm 9.2 \mathrm{a}^{\mathrm{w}}$ & $10.2 \pm 0.2 \mathrm{a}$ \\
F-LED10 & 60.5 & $620.1 \pm 35.8 \mathrm{a}$ & $10.2 \pm 0.6 \mathrm{a}$ \\
M-LED30 & 74.1 & $629.8 \pm 13.2 \mathrm{a}$ & $8.5 \pm 0.2 \mathrm{~b}$ \\
F-LED30 & 72 & $621.9 \pm 6.4 \mathrm{a}$ & $8.6 \pm 0.1 \mathrm{~b}$ \\
FL & 105 & $438.7 \pm 15.8 \mathrm{~b}$ & $4.2 \pm 0.2 \mathrm{c}$ \\
\hline
\end{tabular}

${ }^{2}$ Calculated based on the power consumption of each treatment; $1 \mathrm{kWh} / \mathrm{m}^{2}=0.0929 \mathrm{kWh} / \mathrm{ft}^{2}$

${ }^{y}$ Calculated based on the leaf fresh weight (FW) of each treatment; $1 \mathrm{~g} \cdot \mathrm{m}^{-2}=0.0033 \mathrm{oz} / \mathrm{ft}^{2}$.

${ }^{x}$ Light utilization efficiencies were estimated by dividing the yield $\left(\mathrm{g} \cdot \mathrm{m}^{-2}\right)$ by electricity consumption of lighting per area; $\mathrm{l} \mathrm{g} / \mathrm{kWh}=0.0353 \mathrm{oz} / \mathrm{kWh}$.

${ }^{w}$ Data were analyzed by analysis of variance, and different letters within the column indicate significant differences at $P \leq 0$. 05 according to least significant difference test. 
distance, is $10 \mathrm{~cm}$. For the FL, considering the heat they released to the canopy, $10-\mathrm{cm}$ treatment was not employed.

M-LED 0 consumed almost the same amount of energy as did FLED 10, as well as in M-LED30 and F-LED30. It might be because the total light energy uses of M-LEDl0 and M-LED30 were doubled due to the illumination duration, which was twice as long as in the corresponding fluorescent treatments. This increased illumination duration was offset by halving the LED panels employed in the experiment through the movable system, illustrating that the reduced energy consumption contributed to a lower luminous intensity, as did the reduction in distance. To manifest the profits of the movable system in reducing the initial investment cost of the light sources, an improved movable system was built. The $\$ 40$ device could provide the same function as the prototype used in the experiments, considerably reducing the investment cost according to the price of light sources used.

Plant growth. The lettuce growth was significantly affected by different DLIs in treatments with different $P P F$ on plant canopy. For the treatments (M-LEDI0 and F-LEDI0) employed a fixed distance of $10 \mathrm{~cm}$ above the plants, sustained PPF of 150 $\mu \mathrm{mol} \cdot \mathrm{m}^{-2} \cdot \mathrm{s}^{-1}$ resulted in a constant high DLI value of $12.96 \mathrm{~mol} \cdot \mathrm{m}^{-2} \cdot \mathrm{d}^{-1}$. For the treatments (M-LED30 and FLED30) provided variable $P P F$ at different growth stages $\left(50 \mu \mathrm{mol} \cdot \mathrm{m}^{-2} \cdot \mathrm{s}^{-1}\right.$ early, $150 \mu \mathrm{mol} \cdot \mathrm{m}^{-2} \cdot \mathrm{s}^{-1}$ late) with the increase of plant height, variable DLI values were ranged from 4.32 to 12.96 $\mathrm{mol} \cdot \mathrm{m}^{-2} \cdot \mathrm{d}^{-1}$ (Table $\left.\mathrm{l}\right)$.

Notable positive effects were observed in all LED treatments (Table 3). This may be explained by the beneficial effects of higher red light fraction and $\mathrm{R} / \mathrm{B}$ in LED light sources, as well as the negative effect of green light on biomass production in FL (Folta and Childers, 2008). The blue light fraction in FL may be too high to induce beneficial effects on plant growth, in previous study (Dougher and Bugbee, 2001), overhigh blue fraction may not effectively interact with the plant.

All parameters were not significantly different between M-LEDI0 and F-LEDI0 as well as between MLED30 and M-LED30 (Table 3), suggesting that the DLI might be the main effect variable on plant growth. The reversed photoperiod provided by the different illumination schedules in our study had no significant effects on plant growth.

The true leaf number and leaf length displayed opposing trends under M-LED (M-LED 10, M-LED 30) and F-LED (F-LEDI0, F-LED 30). The true leaf number of M-LEDI0 and F-LEDl0 were $9.4 \%$ and $7.4 \%$ more than that in M-LED30 and FLED30, respectively, and increased with decreasing distance above the canopy. Our results suggested that M-LEDI 0 and F-LEDI0 could provide constant high DLI and maintain rapid lettuce growth, allowing it to gain more leaves during this stage, agreeing with the results observed in lettuce plug transplants (Kitaya et al., 1998). There is also evidence of strong light interception during the early growth stages of lettuce (Tei et al., 1996). On the contrary, the leaf lengths of M-LEDl0 and F-LEDI0 decreased by $9.3 \%$ and $13.7 \%$ compared with M-LED30 and F-LED30, respectively. These results indicate that the relatively low DLI at the early stage of growth in M-LED30 and F-LED30 may have stimulated leaf elongation to receive more light.
In this study, the variations in true leaf number and leaf length demonstrated the nonsignificant effects of the illumination distance above the canopy and of the illumination schedule on the leaf FW in the LED treatments. This was most likely due to the low radiation use efficiency caused by the mutual shading by the leaves within the plant canopy and the high respiration cost of the production and maintenance of leaves (Tei et al., 1996).

Phytochemical accumulation. The phytochemical concentrations in the lettuce leaves were significantly affected by the different light treatments (Table 4 ). Chl a was present in similar concentrations in all of the treatments and appeared to be synthesized at a higher rate than $\mathrm{Chl} b$, perhaps because of the wider absorption spectrum of the Chl a pigment. Furthermore, the applied $P P F$ level reached the minimal $P P F$ essential for $\mathrm{Chl}$ a saturation synthesis.

The Chl b concentration was greatest under FL, at $28.6 \%$ more than in all LED treatments, possibly because the high PPF of blue light in FL (Table 1) plays an important role in Chl synthesis, as discussed in previous results (Kurilčik et al., 2008; Li et al., 2012; Poudel et al., 2008; Senger, 1982). High utilization efficiency under LED lights (Saebo et al., 1995 ) and a "dilution" effect because of the enhancement of DW ( $\mathrm{Li}$ and Kubota, 2009) may also be possible.

The sucrose concentrations of M-LED30 and F-LED30 increased by $49.6 \%$ and $48.5 \%$ (Table 4 ), respectively, compared with the corresponding M-LEDl0 and F-LEDI0. The fructose and glucose concentrations were similar among all treatments. As a desirable parameter in

Table 3. Lettuce fresh weight (FW), plant height, true leaf number and leaf length for lettuce under fluorescent lamps (FL), four light-emitting diode (LED) panels fixed $30 \mathrm{~cm}$ (11.8 inches) directly above the seedling (F-LED30), two LED panels attached to the movable system $30 \mathrm{~cm}$ above the seedlings (M-LED30), two LED panels attached to the movable system 10 $\mathrm{cm}$ (3.9 inches) above the seedlings (M-LED10), and four LED panels fixed $10 \mathrm{~cm}$ directly above the seedlings (F-LED10).

\begin{tabular}{lcccc}
\hline Treatment & $\begin{array}{c}\text { Leaf FW } \\
{[\text { mean } \pm \text { SD }(\mathbf{g})]^{\mathrm{z}}}\end{array}$ & $\begin{array}{c}\text { Plant ht } \\
{[\text { mean } \pm \text { SD }(\mathbf{c m})]^{\mathrm{z}}}\end{array}$ & $\begin{array}{c}\text { True leaves } \\
{[\text { mean } \pm \text { SD }(\mathbf{n o})]}\end{array}$ & $\begin{array}{c}\text { Leaf length } \\
{[\mathrm{mean} \pm \mathrm{SD}(\mathbf{c m})]}\end{array}$ \\
\hline M-LED10 & $34.8 \pm 0.5 \mathrm{a}^{\mathrm{y}}$ & $15.4 \pm 0.3 \mathrm{a}$ & $23.2 \pm 0.3 \mathrm{a}$ & $15.6 \pm 0.2 \mathrm{~b}$ \\
F-LED10 & $35.4 \pm 1.1 \mathrm{a}$ & $15.1 \pm 0.3 \mathrm{a}$ & $22.8 \pm 0.3 \mathrm{a}$ & $15.1 \pm 0.5 \mathrm{~b}$ \\
M-LED30 & $34.6 \pm 0.8 \mathrm{a}$ & $15.6 \pm 0.2 \mathrm{a}$ & $21.2 \pm 0.2 \mathrm{~b}$ & $17.2 \pm 0.3 \mathrm{a}$ \\
F-LED30 & $34.5 \pm 1.9 \mathrm{a}$ & $15.4 \pm 0.2 \mathrm{a}$ & $21.6 \pm 0.3 \mathrm{~b}$ & $17.5 \pm 0.3 \mathrm{a}$ \\
FL & $24.4 \pm 0.9 \mathrm{~b}$ & $13.5 \pm 0.4 \mathrm{~b}$ & $16.9 \pm 0.2 \mathrm{c}$ & $12.4 \pm 0.2 \mathrm{c}$ \\
\hline
\end{tabular}

${ }^{2} 1 \mathrm{~g}=0.0353 \mathrm{oz}, 1 \mathrm{~cm}=0.3937$ inch

'Data were analyzed by analysis of variance, and different letters within the column indicate significant differences at $P \leq 0.05$ according to least significant difference test. 
Table 4. Concentrations of chlorophyll a (Chl a), chlorophyll b (Chl b), fructose, glucose, sucrose, and ascorbic acid of lettuce under fluorescent lamps (FL), four light-emitting diode (LED) panels fixed $30 \mathrm{~cm}$ (11.8 inches) directly above the seedling (F-LED30), two LED panels attached to the movable system $30 \mathrm{~cm}(11.8$ inches) above the seedlings (M-LED30), two LED panels attached to the movable system $10 \mathrm{~cm}$ (3.9 inches) above the seedlings (M-LED10), and four LED panels fixed $10 \mathrm{~cm}$ (3.9 inches) directly above the seedlings (F-LED10).

\begin{tabular}{|c|c|c|c|c|c|c|}
\hline Treatment & $\begin{array}{c}\text { Chl a }[\text { mean } \pm \\
\text { SD }\left(\mathbf{m g} \cdot \mathbf{g}^{-1}\right. \\
\text { FW })]^{\mathrm{z}}\end{array}$ & $\begin{array}{c}\text { Chl b }[\text { mean } \pm \\
\text { SD }\left(\mathrm{mg} \cdot \mathrm{g}^{-1}\right. \\
\text { FW })]\end{array}$ & $\begin{array}{c}\text { Fructose }[\text { mean } \pm \\
\text { SD }\left(\mathbf{m g} \cdot \mathbf{g}^{-1}\right. \\
\text { DW) }]^{\mathrm{z}}\end{array}$ & $\begin{array}{c}\text { Glucose }[\text { mean } \pm \\
\text { SD }\left(\mathrm{mg} \cdot \mathrm{g}^{-1}\right. \\
\mathrm{DW})]\end{array}$ & $\begin{array}{l}\text { Sucrose }[\text { mean } \pm \\
\text { SD }\left(\mathrm{mg} \cdot \mathrm{g}^{-1}\right. \\
\mathrm{DW})]\end{array}$ & $\begin{array}{c}\text { Ascorbic acid [mean } \pm \\
\text { SD }\left(\mathrm{mg} \cdot \mathrm{g}^{-1}\right. \\
\mathrm{DW})]\end{array}$ \\
\hline 10 & $0.25 \pm 0.00 a$ & $14 \pm 0$ & $21.32=$ & $9.06 \pm$ & 25.56 & $2.29 \pm$ \\
\hline F-LEDI0 & $0.25 \pm 0.01 \mathrm{a}$ & $0.14 \pm 0.00 \mathrm{~b}$ & $20.82 \pm 2.18 \mathrm{a}$ & $8.89 \pm 0.56 \mathrm{a}$ & $26.78 \pm 0.96 b$ & $2.11 \pm$ \\
\hline M-LED30 & $0.25 \pm 0.00 \mathrm{a}$ & $0.14 \pm 0.02 \mathrm{~b}$ & $17.05 \pm 2.21 \mathrm{a}$ & $8.75 \pm 1.05 a$ & $38.28 \pm 1.38 \mathrm{a}$ & $0.97 \pm 0.27 \mathrm{c}$ \\
\hline F-LED30 & $0.25 \pm 0.00 \mathrm{a}$ & $0.15 \pm 0.01 \mathrm{~b}$ & $16.35 \pm 1.89 \mathrm{a}$ & $8.69 \pm 0.62 \mathrm{a}$ & $39.83 \pm 2.24 \mathrm{a}$ & $1.06 \pm 0.15 \mathrm{c}$ \\
\hline FL & $0.25 \pm 0.00 \mathrm{a}$ & $0.18 \pm 0.02 \mathrm{a}$ & $17.03 \pm 3.31 \mathrm{a}$ & $9.40 \pm 1.33 \mathrm{a}$ & $30.32 \pm 3.48 b$ & $1.48 \pm 0.01 \mathrm{~b}$ \\
\hline
\end{tabular}

${ }^{\mathrm{z}} \mathrm{FW}=$ fresh weight, $\mathrm{DW}=$ dry weight; $1 \mathrm{mg} \cdot \mathrm{g}^{-1}=1000 \mathrm{ppm}$.

${ }^{y}$ Data were analyzed by analysis of variance, and different letters within the column indicate significant differences at $P \leq 0.05$ according to least significant difference test.

terms of food quality (Lin et al., 2013) and the most sensitive response to primary photosynthesis production (Lefsrud et al., 2008), sugars are not only the direct products of photosynthesis storage, accumulation, and transportation but also the primary substrates of respiration. The higher the sucrose levels, the less fructose and glucose were observed in all treatments in this study; it may be because the sugar concentrations in plant tissue rely on the balance between their synthesis and consumption. The low sucrose concentrations in M-LEDI0 and F-LEDl 0 may indicate that the constant high $P P F$ kept the plants at a high photosynthetic rate and that the sucrose might decompose into fructose and glucose, as shown in Table 4.

In contrast to previous studies (Li and Kubota, 2009), the ascorbic acid concentrations in F-LEDI0 and M-LEDI0 increased by $42.6 \%$ and $54.7 \%$, respectively, but were reduced by $28.4 \%$ and $34.5 \%$ in F-LED 30 and M-LED30 compared with the FL treatment, respectively (Table 4). Neither result is completely in accordance with the report that the ascorbic acid content in leaf lettuce is significantly increased under supplemental red and blue LED light when compared with white FL (OhashiKaneko et al., 2007) nor do these results completely contradict the conclusion that the supplemental green light component had a significant positive effect on ascorbic acid accumulation (Samuolienè et al., 2012). The results of our study may be explained by the interaction effect between PPF and green light. Throughout the growth period, the constant high PPF of M-LEDI0 and
F-LEDI0 produced an even greater impact on the ascorbic acid accumulation than did the green light in FL (Table 1), whereas the increased PPF in M-LED30 and F-LED30 did not reach an adequate density to bring about an equal effect due to green light. The crucial stage of growth for inducing $P P F$, green light, or both may also be a factor.

\section{Conclusions}

Our results demonstrated that the illumination schedule employed in this study (M-LEDl0 and MLED30) can halve the initial light source input while resulting in no differences in electricity consumption, morphological parameters, or phytochemical accumulation compared with F-LED10 and F-LED30. Irrespective of the illumination schedule, the DLI value determined by the distance between light source and lettuce played an important role in the electricity savings and plant quality. As demonstrated by M-LED10 and F-LEDI0, a consistently high PPF and lower luminous intensities resulted in massive electricity savings and significant increases in the true leaf number and ascorbic acid concentrations compared with those under increasing PPF (M-LED30 and F-LED30). A shorter illumination distance did not always have positive effects as reductions in the leaf length and sucrose concentration were observed. We conclude that the use of M-LED systems in plant factories with artificial lighting will bring about considerable economic benefits due to the lower light source input and reduced electricity consumption in addition to increasing plant production. Although only crops that are tolerant to photoperiods of $12 \mathrm{~h}$ or less can be cultivated by this method, many species suitable for plant factories are nonetheless available.

\section{Literature cited}

Association of Official Analytical Chemists International. 2006. AOAC Official Method 982.14. AOAC Intl., Gaithersburg, MD.

Bao, S.S., Q.C. Yang, J. Wen, and J. Xiao. 2008. Preliminary exploration of photovoltaic power generating system in plant factory (in Chinese). J. Agr. Sci. Technol. 10:71-74.

Dougher, T.A.O. and B. Bugbee. 2001. Differences in the response of wheat, soybean and lettuce to reduced blue radiation. Photochem. Photobiol. 73:199207.

Elsevier Science. 2006. LED lighting helps Wal-Mart save energy. III-Vs Rev. 19:12.

Folta, K.M. 2004. Green light stimulates early stem elongation, antagonizing lightmediated growth inhibition. Plant Physiol. 135:1407-1416.

Folta, K.M. and K.S. Childers. 2008. Light as a growth regulator: Controlling plant biology with narrow-bandwidth solid-state lighting systems. HortScience 43:1957-1964.

Folta, K.M. and S.A. Maruhnich. 2007. Green light: A signal to slow down or stop. J. Expt. Bot. 58:3099-3111.

Gahler, S., K. Otto, and V. Böhm. 2003. Alterations of vitamin C, total phenolics, and antioxidant capacity as affected by processing tomatoes to different products. J. Agr. Food Chem 51(27):79627968.

Hahn, E.J., Y.B. Lee, and C.H. Ahn. 1996. A new method on mass-production of micropropagated chrysanthemum 
plants using microponic system in plant factory. Acta Hort. 440:527-532.

Hogewoning, S.W., G. Trouwborst, H. Maljaars, H. Poorter, W.V. Leperen, and J. Harbinson. 2010. Blue light does-responses of leaf photosynthesis, morphology, and chemical composition of Cucumis satious grown under different combinations of red and blue light. J. Expt. Bot. 61:31073117.

Hu, M.H., Y.S. Ao, X.E. Yang, and T.Q. Li. 2008. Treating eutrophic water for nutrient reduction using an aquatic macrophyte (Ipomoea aquatica Forsskal) in a deep flow technique system. Agr. Water Mgt. 95:607-615.

Ikeda, A., Y. Tanimura, K. Ezaki, Y. Kawai, S. Nakayama, K. Iwao, and H. Kageyama. 1992. Environmental control and operation monitoring in a plant factory using artificial light. Acta Hort. 304:151-158

Ioslovich, I. and P.O. Gutman. 2000. Optimal control of crop spacing in a plant factory. Automatica 36:1665-1668.

Johkan, M., K. Shoji, F. Goto, S. Hahida, and T. Yoshihara. 2012. Effect of green light wavelength and intensity on photomorphogenesis and photosynthesis in Lactuca sativa. Environ. Expt. Bot. 75:128-133.

Kato, K., R. Yoshida, A. Kikuzaki, T. Hirai, H. Kuroda, K. Hiwasa-Tanase, K. Takane, H. Ezura, and T. Mizoguchi. 2010. Molecular breeding of tomato lines for mass production of miraculin in a plant factory. J. Agr. Food Chem. 58:95059510 .

Kim, H.H., G.D. Goins, R.M. Wheeler, and J.C. Sager. 2004. Green-light supplementation for enhanced lettuce growth under red- and blue-light-emitting diodes. HortScience 39:1617-1622.

Kitaya, Y., G. Niu, T. Kozai, and M. Ohashi. 1998. Photosynthetic photon flux, photoperiod, and $\mathrm{CO}_{2}$ concentration affect growth and morphology of lettuce plug transplants. HortScience 33:988-991.

Kurilčik, A., R. Miklušyte-Č́anova, S. Dapkūnienè, S. Žilinskaitè, G. Kurilčik, G. Tamulaitis, P. Duchovskis, and A. Zukauskas. 2008. In vitro culture of chrysanthemum plantlets using light-emitting diodes. Central European J. Biol. 3:161167.

Lefsrud, M.G., D.A. Kopsell, and C.E. Sams. 2008. Irradiance from distinct wavelength light-emitting diodes affects secondary metabolites in kale. HortScience 43:2243-2244.

Li, H.M., C.M. Tang, Z.G. Xu, X.Y. Liu, and X.L. Han. 2012. Effects of different light sources on the growth of non-heading chinese cabbage (Brassica campestris L.). J. Agr. Sci. 4:262-273.

Li, H.M., Z.G. Xu, and C.M. Tang. 2010. Effect of light emitting diodes on growth and morphogenesis of upland cotton (Gossypium hirsutum L.) plantlets in vitro. Plant Cell Tissue Organ Cult. 103:155163.

Li, Q. and C. Kubota. 2009. Effects of supplemental light quality on growth and phytochemicals of baby leaf lettuce. Environ. Expt. Bot. 67:59-64.

Lichtentaler, H.K. and A.R. Wellburn. 1983. Determinations of carotenoids and chlorophylls $a$ and $b$ of leaf extracts in different solvents. Biochem. Soc. Trans. 11:591-592.

Lin, K.H., M.Y. Huang, W.D. Huang, M.H. Hsu, Z.W. Yang, and C.M. Yang. 2013. The effects of red, blue, and white light-emitting diodes on the growth, development, and edible quality of hydroponically grown lettuce (Lactuca sativa L. var. capitata). Sci. Hort. 150:86-91.

Matsushita, Y., T. Azuno, and Y. Yamashita. 2012. Fuel reduction in coastal squid jigging boats equipped with various combinations of conventional metal halide lamps and low-energy LED panels. Fish. Res. 125-126:14-19.

McAvoy, R.J., H.W. Janes, and G.A. Giacomelli. 1989. Development of a plant factory model: I. The organizational and operational model II. A plant growth model: The single truss tomato crop. Acta Hort. 248:85-94.

Morimoto, T., T. Torii, and Y. Hashimoto. 1995. Optimal control of physiological processes of plants in a green plant factory. Control Eng. Pract. 3:505-511.

Murase, H. 2000. Development of microprecision agriculture by plant factory. J. Soc. High Technol. Agr. 12:99-104.

Nishimura, M., T. Kozai, C. Kubota, and C. Chun. 2001. Analysis of electric energy consumption and its cost for a closed-type transplant production system. J. Soc. High Technol. Agr. 13:204-209.

Ohashi-Kaneko, K., M. Takase, N. Kon, K. Fujiwara, and K. Kurata. 2007. Effect of light quality on growth and vegetable quality in leaf lettuce, spinach and komatsuna. Envrion. Control Biol. 45:189198.
Ohyama, K., M. Fujiwara, T. Kozai, and C. Chun. 2001. Consumption of electric energy and water for eggplant plug transplant production in a closed-type transplant production system. J. Soc. High Technol. Agr. 13:1-6.

Poudel, P.R., I. Kataoka, and R. Mochioka. 2008. Effect of red- and blue-light-emitting diodes on growth and morphogenesis of grapes. Plant Cell Tissue Organ Cult. 92:147-153.

Ryckaert, W.R., K.A.G. Smet, I.A.A. Roelandts, M.V. Gils, and P. Hanselaer. 2012. Linear LED tubes versus fluorescent lamps: An evaluation. Energy Build. 49:429-436

Saebo, A., T. Krekling, and M. Appelgren. 1995. Light quality affects photosynthesis and leaf anatomy of birch plantlets in vitro. Plant Cell Tissue Organ Cult. 41:177-185.

Sager, J.C., W.O. Smith, J.L. Edwards, and K.L. Cyr. 1982. Photosynthetic efficiency and phytochrome photoequilibria determination using spectral data. Trans. Amer. Soc. Agr. Eng. 31:1882-1889.

Samuolienè, G., R. Sirtautas, A. Brazaitytè, and P. Duchovskis. 2012. LED lighting and seasonality effects antioxidant properties of baby leaf lettuce. Food Chem. 134:1494-1499.

Senger, H. 1982. The effect of blue light on plants and microorganisms. Photochem. Photobiol. 35:911-920.

Tei, F., A. Scaife, and D.P. Aikman. 1996. Growth of lettuce, onion, and red beet. 1 . Growth analysis, light interception, and radiation use efficiency. Ann. Bot. (Lond.) 78:633-643

Wen, J. 2009. Influence of wave crest and $\mathrm{R} / \mathrm{B}$ of red and blue LED on crop growing in the closed plant factory (in Chinese). Chinese Acad. Agr. Sci. MS Diss. Abstr. p. 16-19.

Yamada, C., K. Ohyama, and T. Kozai. 2000. Photosynthetic photon flux control for reducing electric energy consumption in a closed-type transplant production system. Envrion. Control Biol. 38:255261.

Zeng, H., J. Qiu, X.F. Shen, G.J. Dai, P. Liu, and S.P. Le. 2011. Fuzzy control of LED tunnel lighting and energy conservation. Tsinghua Sci. Technol. 16:576582 . 